\title{
GEOCHRONOLOGY OF THE PLEISTOCENE AND HOLOCENE IN THE FORE-URALS
}

\section{E. K. LATYPOVA AND B. L. YAKHEEMOVICH}

Institute of Geology, Ufa Science Centre, Russian Academy of Science, October Revolution 10 Ufa 450025 Russia

ABSTRACT. The paper presents the results for the ${ }^{14} \mathrm{C}$ dating obtained recently in the Laboratory of the Institute of Geology, Ufa Science Centre, Russian Academy of Science, on the basis of megafaunal bones, peats, wood and mollusk shells. Dates are reported in stratigraphic sequence from the Late Würmian to the Holocene.

We applied radiocarbon dating along with biostratigraphical, geomorphological and other methods to study Pleistocene and Holocene deposits of the Fore-Urals, which comprise the part of the East European Plain adjoining the Urals (east of the Volga) from the Caspian basin in the south to the Timan-Uralian depression in the north (Fig. 1). We sampled peat, fossil wood, buried soils, megafaunal bones and mollusk shells from river terraces, lakes, bogs and archaeological sites.

${ }^{14} \mathrm{C}$ dating made it possible to revise the age of the third terrace in the Belaya River basin, which previously was considered as Mikulinian-Kalininian. The age was later estimated as MologianSheksnian-Ostashkovian - regional horizons known in Russia (Yakheemovich 1971) - on the basis of two dates, 21,280 $\pm 550 \mathrm{BP}(\mathrm{LU}-145)$ and 29,700 $\pm 1250 \mathrm{BP}(\mathrm{H}-1856 / 1287)$, obtained from fir stumps near the Gornovo site. Later data supported this conclusion $-22,600 \pm 125$ BP (Bash GI-35) and 28,800 \pm 125 BP (Bash GI-36). ${ }^{1}$ The current stratigraphic scheme (Yakheemovich, Pshenichnyuk and Sidnev 1987) defines these strata as Tabuldinian (Table 1).

Tabuldinian strata were also well dated in other sections. The dates, 25,788 $\pm 100 \mathrm{BP}$ (Bash GI-34) and 27,570 $\pm 480 \mathrm{BP}$ (Bash GI-33), were obtained from wood near Aktanyshbash from the strata containing mammoth, bison and Equus caballus. In addition, ${ }^{14} \mathrm{C}$ data obtained from the Tabuldinian mammoth found at the Sukhoy Kundryak River near Tabulda, Sterlibashevo District, Bashkiria gave the following values: $31,360 \pm 250 \mathrm{BP}$ (LU-2153), 34,910 $\pm 300 \mathrm{BP}$ (LU-2154) and $34,900 \mathrm{BP}$ (LU-1377A). The dates are close to those of the Buribaian mammoth tusk, found on the east slope of the South Urals in the Buribai quarry - 36,000 BP (LU-1380A).

Corresponding ${ }^{14} \mathrm{C}$ dates were obtained previously in the Pechora basin from peat and wood sampled near Garevo, Kipievo, Radionovo and the "Vastyansky Kon" outcrop. The following were obtained from the Garevo peat beds: 43,800 BP (Bash GI-1), 32,740 \pm 700 BP (Bash GI-2), 29,700 $\pm 300 \mathrm{BP}$ (Bash GI-3) and 25,000 $\pm 280 \mathrm{BP}$ (Bash GI-4).

The following dates were obtained from peat beds near Kipievo: 28,580 $\pm 500 \mathrm{BP}$ (Bash GI-16) (from wood) and 24,975 $\pm 165 \mathrm{BP}$ (Bash GI-17) (from peat). The age of the buried peat bog on the Pechora River $5 \mathrm{~km}$ south of Radionovo was dated to $21,840 \pm 220 \mathrm{BP}$ (Bash GI-19) and $36,630 \pm 1280$ BP (Bash GI-20). Both sand bodies from the "Vastyansky Kon" outcrop were dated to $24,790 \pm 500$ BP (Bash GI-8), 26,800 \pm 370 BP (Bash GI-7), 28,380 \pm 270 BP (Bash GI-49), $28,675 \pm 300 \mathrm{BP}$ (Bash Gl-9) and 20,470 $\pm 450 \mathrm{BP}$ (Bash GI-10). However, these data are not considered reliable because the samples from peat beds of the lower Pechora were taken after the Novaya Zemlya nuclear tests, and may be much older.

${ }^{1}$ Bash GI = Institute of Geology, Bashkiria 


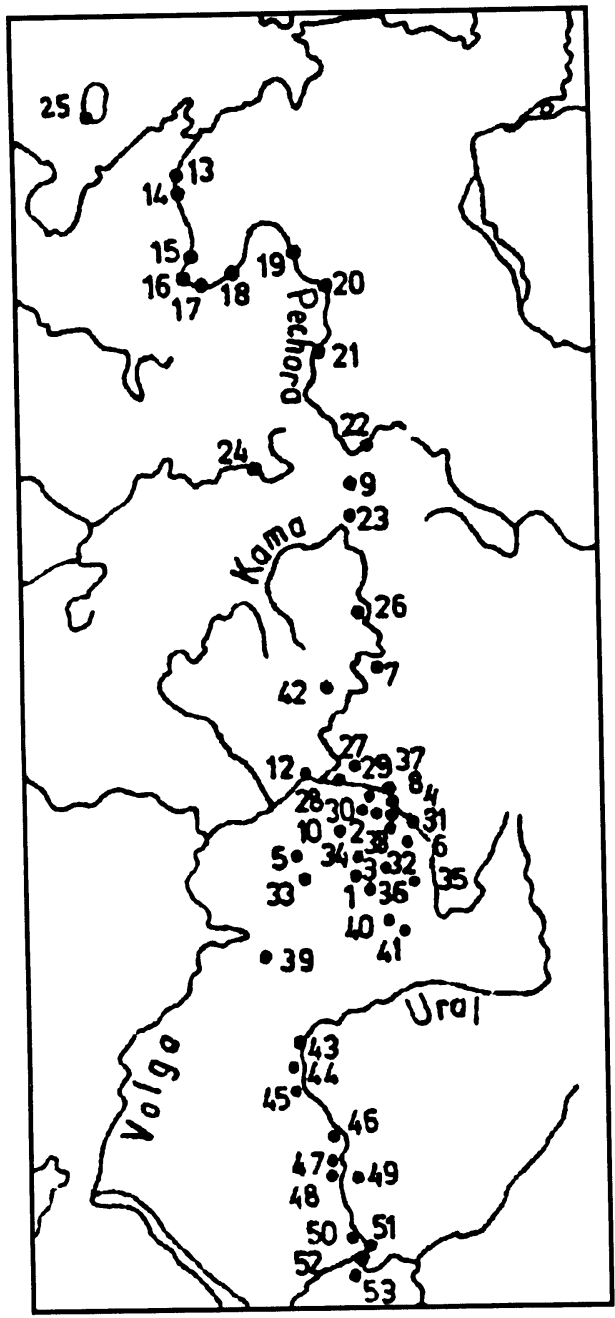

Fig. 1. Locations of sampled sections: 1. Karyatmas; 2. Ishkarovo; 3. Tally-Kulevo; 4. Yukalikul; 5. Kileevo-Ilikovo; 6. Burnak; 7. Koyanovo; 8. Kushnarenkovo; 9. Bogatyrevo; 10. Abdullino; 11. Syun 1 (Kholodny Klyuvh) and 2; 12. Krasny Bor; 13. Velikovisochnaya; 14. Vastyansky Kon; 15. Khabarikha; 16. Ust-Tsilma; 17. Garevo; 18. Kipievo; 19. Radionovo; 20. Byzovaya; 21. Dutovo; 22. Kurya; 23. Nizva; 24. Kaman-El; 25. Kolguev; 26. Sludka; 27. Orya (Staroye Kudashevo); 28. Aktanyshbash; 29. Chui-Atasevo; 30. Novo Sultanbekovo; 31. Gornova; 32. Ctarye Tukmakly; 33. Mullino; 34. Sumbugino; 35. Karmaskaly; 36. Romanovka; 37. Utyagan; 38. Ishbulatovo; 39. Domashkinsky Hills (Domashkinskiye Vershiny); 40. Tabulda; 41. Zlatoustovka; 42. Sharkan; 43. Kozhekharovsky; 44. Chapaev; 45. Mergenevo; 46. Kalmykovo; 47. Kharkino; 48. Inder; 49. Inder (lake); 50. Kurilkino; 51. Rakusha; 52, 53. Caspian shore

The Kudishevian (Ostashkovian) strata forming the upper section of the third terrace yielded the most reliable dates. The strata, up to $15 \mathrm{~m}$ thick, overlie the Tabuldinian and characterize periglacial conditions of the most recent glaciation; they also contain mammoth bones. The age of the main stage of the most recent glaciation is established by the dates, 18,310 $\pm 300 \mathrm{BP}$ (Bash GI-41) and 20,000 \pm 2600 BP (Bash GI-40), obtained from Orya River sections near Staroye Kudashevo and Starye Tukmakly.

In the Orya valley, ${ }^{14} \mathrm{C}$ dates on wood from lacustrine loams in Late-Glacial deposits $(12,700 \pm 55$ $\mathrm{BP}$ (Bash GI-42) and 11,680 $\pm 90 \mathrm{BP}$ (Bash GI-43)) place these deposits in the Allerød. A result of $12,330 \pm 120 \mathrm{BP}$ (Bash GI-107) was obtained from Coelodonta antiquitatis teeth found at the Ashkalar River near Zlatoustovka. This appears to be the first report of such a young Allerød or Dryas species (Table 1).

${ }^{14} \mathrm{C}$ dates and pollen analyses from river terraces, peat beds and archaeological sites enabled Nemkova (1978) to designate five Holocene phases: Preboreal, Boreal, Atlantic, Subboreal and Subatlantic. Results of $9620 \pm 50$ BP (Bash GI-76) and $9650 \pm 50$ BP (Bash GI-77) were obtained 
TABLE $1 .{ }^{14} \mathrm{C}$ Dates on Megafaunal Bone

\begin{tabular}{lll}
\hline Climatic-chronological units & ${ }^{14} \mathrm{C}$ dates and sample locations & Sample material \\
\hline $\begin{array}{l}\text { Late Pleistocene } \\
\text { Ostashkovian (Valdaian) } \\
\text { glaciation, late stage }\end{array}$ & & \\
Allerød, Older Dryas, & $12,330 \pm 120$ (LU-1668), & Coelodonta antiquitatis teeth \\
Bølling, Oldest Dryas & Zlatoustovka & \\
& & \\
Mologo-Sheksnian interglaciation & $31,360 \pm 250$ (LE-2153), Tabulda & Mammoth tubular bones \\
& $34,910 \pm 300$ (LE-2154), Tabulda & \\
& $34,900 \pm($ LU-1377 A), Tabulda & \\
& $36,000 \pm($ LU-1380 A), Buribai & Mammoth tusk \\
\hline
\end{tabular}

for the Preboreal phase from the "Kholodny Klyuch" section (Table 2). In most regions of the Bashkirian Fore-Urals, this interval was marked by forest expansion, especially of coniferous and birch species. Treeless plains occurred only in the most southern part of the Fore-Urals.

The following Boreal dates were determined from wood at the Mullino 2 site near Oktyabrsky: $8320 \pm 110 \mathrm{BP}$ (Bash GI-58), $8460 \pm 130 \mathrm{BP}$ (Bash GI-37) and $8500 \pm 180 \mathrm{BP}$ (Bash GI-59). Peat dates of $8510 \pm 150 \mathrm{BP}$ (Bash GI-55) and $8820 \pm 250 \mathrm{BP}$ (Bash GI-56) were obtained near Sharkan in the middle Kama; additional peat dates from Ishbulatovo are $8570 \pm 40 \mathrm{BP}$ (Bash GI-31) and $8880 \pm 60 \mathrm{BP}$ (Bash GI-32). Dates of $9260 \pm 210 \mathrm{BP}$ (Bash GI-83), from the Evbazy River bank near Abdullino, and $8730 \pm 160 \mathrm{BP}$ (Bash GI-13), were also obtained from the upper Pechora near Dutovo. During the Boreal, Bashkiria was characterized by pine-fir forests, with locally abundant linden. Southern Bashkiria was covered by birch-pine forests alternating with steppe plains.

Atlantic deposits formed during the Holocene climatic optimum were reported from only some sections of the Fore-Urals. The dates are as follows: $7100 \pm 150$ BP (Bash GI-68) from the Syun River between Staro-Ilikovo and Kileevo; $7050 \pm 100$ BP (Bash GI-54) from near Sharkan; 6450 \pm 150 BP (Bash GI-75), near Kushnarenkovo; $6300 \pm 200$ BP (Bash GI-72) from near Koyanovo; $5772 \pm 530$ BP (Bash GI-30) from near Sultanbekovo; and $5050 \pm 60$ BP (Bash GI-29) from near Utyagan. During the Atlantic phase, the Bashkiria region was characterized by pine-fir forests while its southern portion was covered with pine forests with birch, linden and minor elm and oak. The end of the phase was marked by the extension of treeless plains. Broad-leaved forests did not dominate during the climatic Holocene optimum in the Bashkiria region, in contrast to most of the central East European Plain.

Many ${ }^{14} \mathrm{C}$ dates are available for the Subboreal, as its deposits are widespread. Dates in the interval from $2630 \pm 110 \mathrm{BP}$ (Bash GI-102) to $4560 \pm 150 \mathrm{BP}$ (Bash GI-85) are presented in Table 2. The dates from Bash GI-1 to Bash GI-67 are reported by Yakheemovich, Pshenichnyuk and Suleimanova (1974). The onset of the Subboreal, in most parts of Bashkiria, was marked by the extension of xerophyte steppes replacing pine-birch forests (north) and birch (south). The maximum of linden forests, especially in northern Bashkiria, was characteristic of the Subboreal.

Far fewer dates are available for the Subatlantic: for example, $900 \pm 90 \mathrm{BP}$ (Bash GI-810) and $1920 \pm 170$ BP (Bash GI-71) (Table 2). These forests contained more fir; the second part of this phase was marked by an increase in deciduous species. At the end of the phase, xerophyte steppes became widespread. In contrast with the Subboreal, no floral changes were evident. The climate became warmer and drier toward the end of the Subatlantic. 
TABLE $2 .{ }^{14} \mathrm{C}$ Dates on Peat and Wood

\begin{tabular}{|c|c|c|}
\hline Climatic-chronological units & ${ }^{14} \mathrm{C}$ dates and sample locations & Sample material and depth (m) \\
\hline \multicolumn{3}{|r|}{ Peat near houndary horizon with } \\
\hline \multirow[t]{4}{*}{ Subatlantic phase } & $900 \pm 90$ (Bash GI-810), Karyatmas & $\begin{array}{l}\text { Peat near boundary horizon with } \\
\text { wood, } 0.7-0.8\end{array}$ \\
\hline & $1380 \pm 80$ (Bash GI-80), Karyatmas & $\begin{array}{l}\text { Peat above boundary horizon, } \\
0.25-0.5\end{array}$ \\
\hline & $1460 \pm 80$ (Bash GI-86), Yukalikul 1 & Wood from boundary horizon, $0.6-0.7$ \\
\hline & $1920 \pm 170$ (Bash GI-71), Ishkarovo & $\begin{array}{l}\text { Peat from workings at the Saryaz } \\
\text { River, } 1.1\end{array}$ \\
\hline \multirow[t]{12}{*}{$\begin{array}{l}\text { Middle Holocene } \\
\text { Subboreal phase }\end{array}$} & $2630 \pm 110$ (Bash GI-102), Ishkarovo & $\begin{array}{l}\text { Peat covering boundary horizon, } \\
1.3-1.4\end{array}$ \\
\hline & $2650 \pm 70$ (Bash GI-82), Karyatmas & Pine from boundary horizon, $1.4-1.6$ \\
\hline & $2720 \pm 130$ (Bash GI-84), Tally Kulevo & Peat ground bed, $0.5-0.6$ \\
\hline & $2760 \pm 60$ (Bash GI-103), Ishkarovo & $\begin{array}{l}\text { Peat from middle part of boundary } \\
\text { horizon, } 1.5-1.6\end{array}$ \\
\hline & $3110 \pm 90$ (Bash GI-104), Ishkarovo & $\begin{array}{l}\text { Wood from lower part of boundary } \\
\text { horizon, } 1.6-1.7\end{array}$ \\
\hline & $3130 \pm 150$ (Bash GI-70), Ishkarovo & $\begin{array}{l}\text { Peat from workings at the Saryaz } \\
\text { River, } 2.75\end{array}$ \\
\hline & $3160 \pm 160$ (Bash GI-88), Yukalikul 2 & Peat, $1.2-1.3$ \\
\hline & $3410 \pm 50$ (Bash GI-89), Yukalikul 2 & Peated carbonate silt, $1.3-1.5$ \\
\hline & $3470 \pm 90$ (Bash GI-LU-729), Karyatmas & Peat with wood, $2.0-2.2$ \\
\hline & $3720 \pm 100($ Bash Gl-87), Yukalikul 2 & Peat with wood, $2.2-2.35$ \\
\hline & $3980 \pm 180$ (Bash GI-69), Kileevo-Ilikovo & \\
\hline & $4560 \pm 150$ (Bash GI-85), Burnak & Peat, 0.65 \\
\hline \multirow[t]{3}{*}{ Atlantic phase } & $6300 \pm 200$ (Bash GI-72), Koyanovo & Peat, 1.5-1.6 \\
\hline & $6450 \pm 150$ (Bash GI-75), Kushnarenkovo & Peat, $0.7-0.9$ \\
\hline & $6850 \pm 150$ (Bash GI-74), Bogatyrevo & Wood \\
\hline \multicolumn{3}{|l|}{ Early Holocene } \\
\hline \multirow[t]{3}{*}{ Boreal phase } & $7100 \pm 150$ (Bash GI-86), Kileevo-Ilikovo & Peat \\
\hline & $7110 \pm 220$ (Bash GI-90), Yukalikul 2 & Buried soil, $1.5-1.8$ \\
\hline & $7620 \pm 90$ (Bash GI-105), Ishkarovo & Peat with wood, 2.6 \\
\hline \multirow[t]{3}{*}{ Preboreal phase } & $9260 \pm 210$ (Bash GI-83), Abdullino & Peat, $1.6-1.7$ \\
\hline & $\begin{array}{l}9620 \pm 50 \text { (Bash GI-76), Kholodny Kly- } \\
\text { uch, Syun } 1\end{array}$ & Sand with coal, $1.2-1.6$ \\
\hline & $\begin{array}{l}9650 \pm 50 \text { (Bash GI-77), Kholodny Kly- } \\
\text { uch, Syun } 1\end{array}$ & Coal, 1.2-1.6 \\
\hline \multirow{5}{*}{\multicolumn{3}{|c|}{$\begin{array}{l}\text { Late Pleistocene } \\
\text { Ostashkovian (Valdaian) } \\
\text { glaciation } \\
\text { Allerød, Older Dryas, } \\
\text { Bølling, Oldest Dryas }\end{array}$}} \\
\hline & & \\
\hline & & \\
\hline & & \\
\hline & & \\
\hline \multirow{3}{*}{$\begin{array}{l}\text { Main stage of Late Würm- } \\
\text { Valdai-Ostashkovian } \\
\text { glaciation }\end{array}$} & $17,000 \pm 100$ (Bash GI-78), Kholodny & Wood, 4.3-4.6 \\
\hline & Klyuch, Syun 1 & \\
\hline & $17,200 \pm 170$ (Bash GI-79), Kholodny & Wood, 4.3-4.6 \\
\hline & & \\
\hline $\begin{array}{l}\text { Mologo-Sheksnian inter- } \\
\text { glaciation }\end{array}$ & $35,650 \pm 180$ (Bash GI-73), Krasny Bor & $\begin{array}{l}\text { Wood from lower part of lacustrine } \\
\text { loams }\end{array}$ \\
\hline
\end{tabular}


Initial ${ }^{14} \mathrm{C}$ data were obtained on the age of the peat boundary horizon in Bashkiria, as well as on the beginning of peat formation (Table 2). Two boundary horizons were defined at the Karyatmas peat bog with dates of $2650 \pm 70 \mathrm{BP}$ (Bash GI-82) for the oldest, and $3470 \pm 90 \mathrm{BP}$ (LU-729) for the surface peat. The dates, $2760 \pm 60 \mathrm{BP}$ (Bash GI-103) and $3110 \pm 90 \mathrm{BP}$ (Bash GI-104), were obtained for the Ishkarovo peat bog, while surface peat was dated at $7620 \pm 90 \mathrm{BP}$ (Bash GI-105). At the Yukalikul peat bog, a layer with abundant fossil wood was dated at $1460 \pm 80 \mathrm{BP}$ (Bash GI-86).

Nemkova (1978) determined peat formation rates of $0.97 \mathrm{~mm} \mathrm{yr}^{-1}$ for the lower part of the Subatlantic and Upper Subboreal, and $0.72 \mathrm{~mm} \mathrm{yr}^{-1}$ for the lower part of the Subboreal at the Karyatmas peat bog. The most favorable conditions for peat formation in the southern Fore-Urals existed during the Subboreal.

Archaeological research established the duration of occupation in the Fore-Urals. Mesolithic cultures developed from the early Dryas to the second part of the Boreal; Neolithic and Eneolithic cultures existed from the middle Boreal to the second part of the Subboreal; the Bronze Age included most of the Subboreal; the onset of the Iron Age occurred at the end of the Subboreal.

In the Ural River valley (North Precaspian region) mollusk shells were sampled at Kozhekharovsky, Chapaev, Mergenevo, Inder, Kharkino, Kurilkino and Rakusha (Table 3), where Bakian, Khazarian, Khvalynian and Novocaspian strata were described (Yakheemovich, Nemkova and Dorofeev 1986). Uranium-series dates were obtained on shells from the Krasnovodsky and Cheleken peninsulas; the samples were analyzed at the Laboratory of Geochronology (Institute of Geography, St. Petersburg State University). The following dates were obtained for the Khazarian deposits from Cheleken: 1) from Didacna pravoslavlevi Fed., 200,000 BP (LU-831A, B) for inner and outer fractions; 2) from Didacna porsugelica Nev., 100,000 \pm 3500 BP (LU-830A) (outer fraction) and 85,000 $\pm 2800 \mathrm{BP}$ (LU-830 B) (inner fraction). The former are of Lower Khazarian age and the latter, Upper Khazarian (Mikulian).

The following dates were obtained by U-series method for the Khvalynian deposits from Krasnovodsky and Cheleken (Table 3): from Didacna delenda Bog., Krasnovodsky peninsula, Kyzyl Burun Mt.: 24,200 \pm 700 BP (LU-826); and from Didacna protracta Eichw.: 16,700 \pm 550 BP (LU-828); these are Lower Khvalynian deposits. The same samples yielded younger duplicate dates by ${ }^{14} \mathrm{C}$ method: $13,920 \pm 740 \mathrm{BP}$ (LU-826) and 11,810 $\pm 450 \mathrm{BP}$ (LU-828). For the same Khvalynian deposits on the western coast of Cheleken, the U-series method yielded a date of 6200 \pm 200 BP (LU-825) from Didacna praetrigonoides Nal., and may correspond to the Late Khvalynian. The samples from the Khvalynian deposits of the lower Ural River also gave a younger date; this probably results from the post-depositional contamination of young carbonate into shells. The following U-series dates were obtained for the Early Khvalynian terrace: 1) Didacna protracta Eichw., D. subpyramidata Prav. at Kozhekharovsky: 11,700 \pm 500 BP (LU-844) and Didacna protracta Eichw.: 13,500 $\pm 700 \mathrm{BP}$ (LU-845); 2) Didacna protracta Eichw. at Chapaev: $8090 \pm 600 \mathrm{BP}(\mathrm{LU}-846 \mathrm{~A})$ and $9500 \pm 400 \mathrm{BP}$ (LU-846C) (cf. 11,830 $\pm 200 \mathrm{BP}$ (LU1433) by ${ }^{14} \mathrm{C}$ dating); 3) Didacna protracta Eichw., at Mergenevo: $11,900 \pm 400 \mathrm{BP}$ (LU-843); 4) Didacna protracta Eichw., northern bank of the Inder River: 14,400 $\pm 400 \mathrm{BP}$ (LU-847A) and $14,900 \pm 400$ BP (LU-847B), both outer and inner fractions, (cf. from Didacna ebersini Fed.: $11,490 \pm 380 \mathrm{BP}$ (LU-1432) by ${ }^{14} \mathrm{C}$ dating).

LU-842, dated to $8850 \pm 700$ BP by U-series method, was obtained near Kharkino from Didacna ebersini Fed. whereas a ${ }^{14} \mathrm{C}$ date yielded $13,540 \pm 130 \mathrm{BP}$ (LU-1409). The following dates were also obtained by ${ }^{14} \mathrm{C}$ method: from Didacna praetrigonoides $\mathrm{Nal}$. and Cardium edule I. at Rakusha: 
TABLE $3 .{ }^{14} \mathrm{C}$ and U-Series Dates on Mollusk Shells

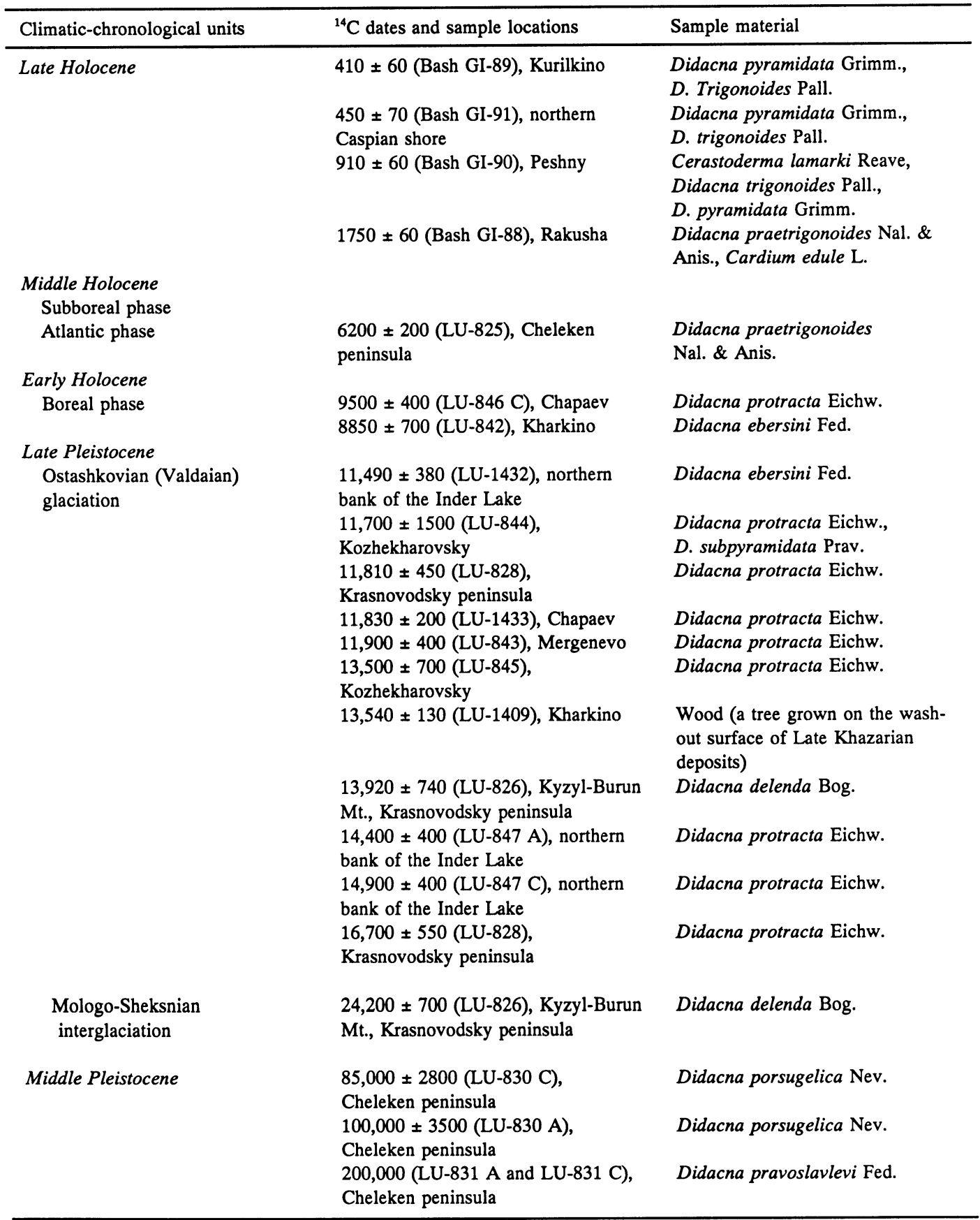

$1750 \pm 60$ BP (Bash GI-88), ${ }^{14} \mathrm{C}$ method; from Didacna pyramidata Grimm. and $D$. trigonoides Pall. at Kurilkino: $410 \pm 60$ BP (Bash GI-89); from Cerastoderma lamarki Raeve, Didacna trigonoides Pall. and $D$. pyramidata Grimm. at Peshny: $910 \pm 60 \mathrm{BP}$ (Bash GI-90), ${ }^{14} \mathrm{C}$ method; from Didacna pyramidata Grimm. and $D$. trigonoides Pall., northern coast of the Caspian Sea: 450 \pm 70 BP (Bash GI-91). 


\section{CONCLUSIONS}

We conclude the following:

1. A considerable break between Lower and Upper Khazarian deposits has been confirmed, the former corresponding to the start of the Middle Pleistocene, and the latter to the beginning of the Late Pleistocene (Mikulian).

2. The age of Lower Khvalynian deposits corresponds to Tabuldinian (Mologo-Sheksnian) strata.

3. Late Khvalynian deposits date to the last glaciation.

\section{REFERENCES}

Nemkova, V. K. 1978 Stratigraphy of late- and postglacial deposits in the Fore-Urals. In On the Late Pleistocene and Holocene in South Urals and ForeUrals. Ufa: 4-45.

Yakheemovich, B. L. 1971 On absolute age of analogs of Mologian-Sheksnian deposits in the Fore-Urals. In Proceedings of All-Union Conference on ${ }^{14} \mathrm{C}$ Variations in the Atmosphere of the Earth and ${ }^{14} \mathrm{C}$ Dating. Vilinius: 229-232.

Yakheemovich, B. L., Nemkova, V. K. and Dorofeev,
P. I. 1986 The Pleistocene of the Lower Ural. Ufa: $134 \mathrm{p}$.

Yakheemovich, B. L., Pshenichnyuk, V. S. and Sidnev, V. I. 1987 The Pleistocene in the Fore-Urals. Moscow: $133 \mathrm{p}$.

Yakheemovich, B. L., Pshenichnyuk, V. S. and Suleimanova, F. I. 1974 The Fore-Urals. In Geochronology of the USSR, Vol. 3, New Stage (Late Pliocene - Quaternary). Leningrad: 165-177. 